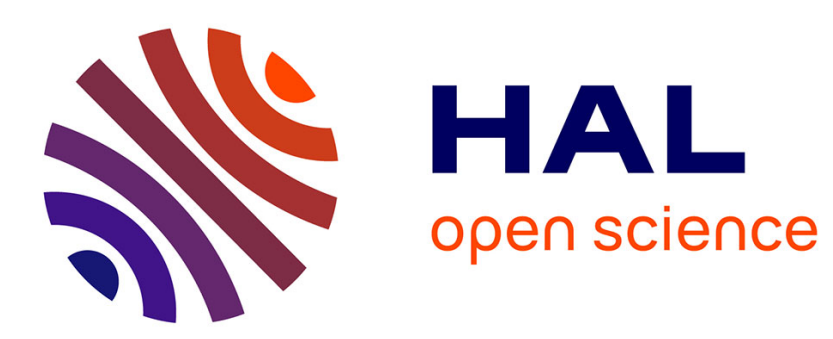

\title{
Effect of yeast culture, Saccharomyces cerevisiae, on ruminal fermentation during adaptation to high-concentrate feeding
}

B Michalet-Doreau, D Morand

\section{- To cite this version:}

B Michalet-Doreau, D Morand. Effect of yeast culture, Saccharomyces cerevisiae, on ruminal fermentation during adaptation to high-concentrate feeding. Annales de zootechnie, 1996, 45 (Suppl1), pp.337-337. hal-00889648

\section{HAL Id: hal-00889648 \\ https://hal.science/hal-00889648}

Submitted on 1 Jan 1996

HAL is a multi-disciplinary open access archive for the deposit and dissemination of scientific research documents, whether they are published or not. The documents may come from teaching and research institutions in France or abroad, or from public or private research centers.
L'archive ouverte pluridisciplinaire HAL, est destinée au dépôt et à la diffusion de documents scientifiques de niveau recherche, publiés ou non, émanant des établissements d'enseignement et de recherche français ou étrangers, des laboratoires publics ou privés. 


\title{
Effect of yeast culture, Saccharomyces cerevisiae, on ruminal fermentation during adaptation to high-concentrate feeding
}

\author{
B Michalet-Doreau, D Morand \\ INRA, Station de Recherches sur la Nutrition des Herbivores, CR de Clermont-Ferrand-Theix, 63122 Saint- \\ Genès-Champanelle, France
}

\begin{abstract}
Changes occurring in the rumen after excessive intake of starch have been studied extensively, but little is known about the critical changes during stepwise adaptation from low to high concentrate diets. Under these unsteady ruminal conditions, the ruminal $\mathrm{pH}$ drops, lactic acid becomes an important intermediate metabolite in the fermentation pathway, and can accumulate rapidly (Mackie and Gilchrist, 1979, Appl Environ Microbiol, 38, 422-436). Moreover, Williams et al (1991, J Anim Sci, 69, 3016-3026) show the role of yeast, Saccharomyces cerevisiae (SC), on the stabilization of ruminal fermentation. The objective of this study was to provide additional informations on this effect of yeast during stepwise adaptation.
\end{abstract}

The effect of the addition of SC (10 7 $\mathrm{CFU} / \mathrm{ml}$ of rumen contents) was studied with 4 ruminally fistulated wethers in a $2 \times 2$ Latin square design. All diets were fed twice daily at the level of $850 \mathrm{~g}$ dry matter. The initial diet contained $90 \%$ hay and $10 \%$ soya meal. At weekly intervals and during 5 weeks, increasing proportions of hay were replaced by ground barley until the final diet contained $70 \%$ barley, $20 \%$ hay and 10\% soyameal. During the 5 adaptation weeks, ruminal liquid was collected using a suction pump $1 \mathrm{~h}$ before feeding, 1, 2, 3, 4, 6 and $8 \mathrm{~h}$ after feeding on 2 consecutive days of each week. Ruminal liquid $\mathrm{pH}$ was measured immediately after sampling, $D$ - and L-lactic acids were determined enzymatically and volatile fatty acids (VFA) by gas liquid chromatography (Jouany, 1992, Sci Alim, 2, 131-144).

The $\mathrm{pH}$ decreased when the grain content in the diet increased, and reached the lowest values $3 \mathrm{~h}$ after feeding irrespective of the diet.
The presence of SC increased significantly the mean ruminal $\mathrm{pH}$ (5.87 vs 5.53 ) on the $70 \%$ grain diet (70 diet). Lactic acid appeared in large proportions in the rumen only on 70 diet with a peak about $2 \mathrm{~h}$ after the meal of barley. Both D- and L-lactic acids were found, the Disomer constituting from 50 to $90 \%$ of the total respectively on 0 and 70 diets. The presence of $\mathrm{SC}$ suppressed in an overall lower $(0.397$ vs $0.211 \mathrm{~g} / \mathrm{l})$ level of D-lactic acid with the 70 diet. Yeast prevented the peak in lactic acid, and reduced the variations between animals, high with this diet. The concentration of total VFA increased regularly with barley content in the diet, from 82.5 to $105.9 \mathrm{mM} / \mathrm{l}$, and the molar proportion of acetic acid in the total VFA decreased (69.8 to $60.0 \%$ ). The molar concentration of VFA in the rumen of animals given the forage diet tended to be higher in animals given SC ( 86.2 vs $82.5 \mathrm{mM} / \mathrm{l})$ probably due to a beneficial effect of $S C$ on cellulolysis. In contrast $S C$ tended to cause a reduction in molar concentration of VFA in concentrate diets. This was attributed to decrease in VFA production or increase in absorption in relation to the $\mathrm{pH}$ decrease. On the other hand, the molar proportions of acetic, propionic and butyric acids in the total VFA were not modified in animals given SC compared with control animals.

During stepwise adaptation to a high concentrate diet, addition of yeast culture may stabilize the ruminal fermentations, and reduce the large variability between animals observed with these diets which induce unsteady conditions in the rumen. 